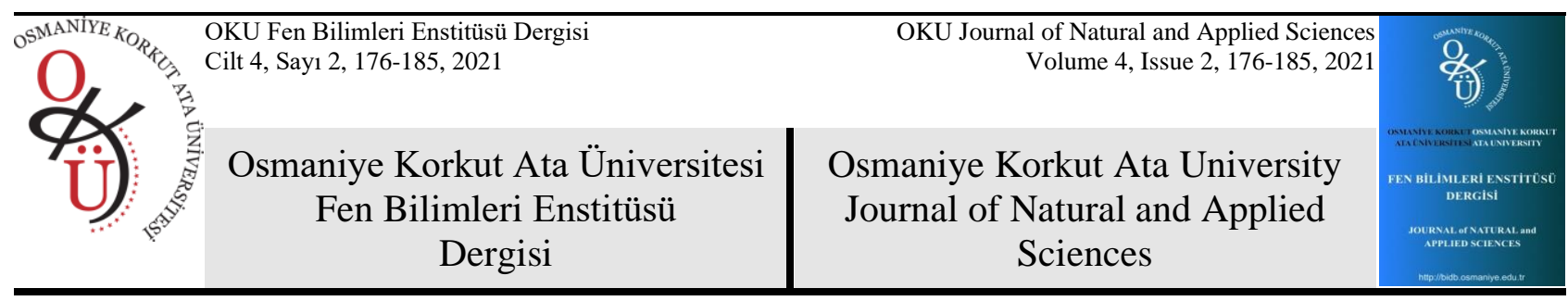

\title{
Etlik Piliçlerde Erken Dönem Besleme Uygulamaları
}

\author{
Meltem TUFAN $^{1 *}$, Şefika EVREN ${ }^{2}$ \\ ${ }^{1}$ Muş Alparslan Üniversitesi Uygulamalı Bilimler Fakültesi, Hayvansal Üretim ve Teknolojileri Bölümü 49250, Muş \\ ${ }^{2}$ Çukurova Üniversitesi, Ziraat Fakültesi, Zootekni Bölümü, Sarıçam, Adana
}

${ }^{1}$ https://orcid.org/0000-0002-3804-7571

${ }^{2}$ https://orcid.org/0000-0003-3096-4866

*Sorumlu yazar: meltemkalkantufan@gmail.com

\section{Derleme}

\section{Makale Tarihçesi:}

Gelis tarihi: 23 Kasım 2020

Kabul tarihi: 6 Şubat 2021

Online Yayınlanma: 1 Haziran 2021

\section{Anahtar Kelimeler:}

Broyler

Erken dönem

Besleme

Ön başlatma

İn ovo

Performans

\section{ÖZET}

Piliç etinin özellikle gelişmekte olan ülkelerde insanların hayvansal protein ihtiyaçlarının karşılanmasında önemli bir potansiyele sahip olduğu bilinen bir gerçektir. İnsan beslenmesinde piliç eti, tat ve lezzetinin yanı sıra ucuz ve kaliteli protein kaynaklarının başında gelmektedir. Etlik piliç üretiminde amaç, hızlı büyüyen, yemden daha iyi yararlanan ve kaliteli karkas üreten piliçler yetiştirmektir. Gelişim hızı direk olarak hayvanın genetik özelliği, fizyolojisi ve metabolizması ile yakından ilgilidir. Bu üstün materyalden beklenen üretim potansiyelinin elde edilebilmesi için etlik piliçlerin optimal koşullarda yetiştirilmesi gerekir. Üretimde verimi etkileyen koşullarından en önemlilerinden biri beslemedir. Günümüzde standart besleme yöntemlerine ilave erken dönem besleme olarak bilinen kuluçkadan çıkış öncesi (kuluçka dönemi) ve kuluçkadan çıkış sonrası olmak üzere 2 farklı dönemde beslemeye yönelik araştırmalar yapılmaktadır. İn ovo ve ön başlatma yemi olarak bilinen bu uygulamalar etlik piliç standart besleme periyodunun dışında uygulanan performans arttırmaya yönelik besleme metotlarıdır. Erken dönemde civcivleri besleme, sistemlerinin hızlı ve hassas gelişmelerini tamamlaması için oldukça önemlidir. Yapılan derlemede hızlı gelişen ticari etlik piliçlerin kuluçka sonu ve erken dönem ilk 0-5 gün boyunca ön başlatma yemi ile beslenmesinin önemi ve sonraki dönemlerinde performanslarına etkisi ortaya konulmaya çalışılmıştır.

\section{Early Feeding Practices in Broiler Chickens}

\section{Review Article}

\section{Article History:}

Received: 23 November 2020

Accepted: 6 February 2021

Published online: 1 June 2021

\section{Keywords:}

Broiler

Early period

Feeding

Pre starter

İn ovo

Performance

\begin{abstract}
It is a known fact that chicken meat has an important potential in meeting the animal protein needs of people especially in developing countries. In human nutrition, chicken meat is one of the leading cheap and high quality protein sources besides its taste and flavor. The purpose of broiler chicken production is to raise chickens that grow fast, make better use of feed and produce quality carcass. The rate of growth is directly related to the genetic characteristics, physiology and metabolism of the animal. In order to obtain the production potential expected from this superior material, broilers should be grown under optimal conditions. The most important environmental conditions that determine efficiency in production is feding. Nowadays, researches are carried out on the application of early feeding in addition to standard feeding methods in 2 different periods as the pre-hatching period (incubation period) and the post-hatching period. These applications, known as in ovo and pre-starter feed are feeding methods to increase the performance applied outside the broiler standard feeding period. Feeding chicks in the early period is essential for their systems to complete their rapid and precise development. In this review, the importance of feeding fast growing commercial broiler chickens with pre-starter feed at the end of incubation and
\end{abstract}


early period for the first 0-5 days and its effect on their performance in the following periods were tried to be revealed.

To Cite: Tufan M., Evren Ş. Etlik Piliçlerde Erken Dönem Besleme Uygulamaları. Osmaniye Korkut Ata Üniversitesi Fen Bilimleri Enstitüsü Dergisi 2021; 4(2): 176-185.

\section{Giriş}

Etlik piliç üretimi tüm dünyada 1940'lı y1llardan itibaren gelişme göstererek, domuz etinden sonra en çok üretilen ürün haline gelmiştir [1]. Gelecekte de bu talebin devam ederek, tavuk eti üretim ve tüketimindeki artışların diğer etlerden daha yüksek olacağ 1 beklenmektedir. Taleplerin tavuk eti lehine artmasındaki başlıca etkenler; üretimin kolaylığı, arazi ihtiyacının düşüklüğü, tüm toplumlarda hiçbir yasak olmadan tüketilmesi, üretim süresinin kısalığı, sağlıklı olması ve ucuzluğudur.

Günümüzde piyasaya sunulan etlik civcivler genetik olarak hızlı büyüyen, yemi ete çevirme kabiliyeti yüksek ve iyi karkas oluşturan hayvanlardır. $\mathrm{Bu}$ üstün materyalden beklenen üretim potansiyelinin elde edilebilmesi için etlik piliçlerin optimal koşullarda yetiştirilmesi gerekir. Üretimde verimi belirleyen çevre koşullarından en önemlisi besleme ve yemlemedir. Aynı bakım ve besleme koşullarında etlik civcivlerin ilk haftalardaki gelişim hızı yumurtacı civcivlere göre oldukça yüksektir. Yumurtadan çıkışta yaklaşık 40-42 g olan etlik piliçler çok hızlı gelişir ve 5-6 hafta gibi kısa sürede yaklaşı 2,5-2,8 kg canlı ağırlığa ulaşırlar [2].

Hızlı gelişmeye bağlı olarak, besin madde ihtiyaçları hızlı bir değişim gösterir. $\mathrm{Bu}$ nedenle besin madde ihtiyaçları günlük değil, belirli periyotlar içinde incelenir ve ihtiyacı karşılayacak yemlerle beslenirler.

Etlik piliçler genellikle büyüme hızına ve besin madde gereksinmelerindeki değişime bağlı olarak besi süresince besin madde kompozisyonu farkl1, başlangıç (0-10 gün), büyütme (11-24 gün), bitirme (25-42 gün) olmak üzere üç farklı yemle beslenirler ancak son y1llarda, genetik seleksiyon, bakım, besleme ve sağlıkta sağlanan gelişmeler, kanatlı hayvanların besi performansını artırmakta ve amaçlanan besi sonu canlı ağırlı̆̆ına daha kısa sürede ulaşmalarına imkân vermektedir.

Hayvan ıslahında, bakım ve beslemede sağlanan bu gelişmeler kanatlı hayvan beslemesinde besi sonu canlı ağırlığını artırırken, besi süresini de önemli derecede azaltmaktadır. $\mathrm{Bu}$ durum, kuluçkadan çıkışı takiben gelişmede söz konusu olabilecek bir gecikmede besi performansin olumsuz etkileme riskini de ortaya çıkarmaktadır.

Kuluçkadan çıktıktan sonraki ilk 5 gün erken dönem olarak adlandırılır. Kuluçkadan çıkışı takiben civciv, yeni bir dünya ve dış çevre ile karşılaşmakta, özellikle bu yeni çevreye uyum sağlayarak büyüme ve gelişmeye çalışmaktadır. Kuluçkadan çıkmadan önce embriyo içine çekilen yumurta sarı kesesi, civcivin yaşamının devamı için 72 saatlik su ve diğer temel besin madde gereksinimini karşılamaktadır [3].

Sindirim sistemi hiç gelişmemiş olan civcivin dışarıdan verilen besin maddelerine alışması ve onları sindirebilmesi için zamana ihtiyacı vardır. Civciv çıkışı takip eden ilk haftada canlı ağırlığının 4-5 katına ulaşırken, sindirim sistemi çıkış ağırlığının 10-12 katına ulaşmaktadır. Yani ilk haftada vücuda alınan besin maddelerinin önemli bir kısmı sindirim sisteminin geliştirilmesine harcanmaktadır [4]. Civcivin sindirim sisteminin ve vücut gelişimi ile güçlü bir bağışıklık sisteminin oluşturulması, performans değerlerinin arttırılması, yumurtadan çıkıştan itibaren verilecek yemler ve onların besin madde yapısı, içeriği ve sindirilebilirliği ile de yakından ilgilidir. Civciv yumurtadan çıktığında fizyolojik olarak henüz tam gelişmediği için, erken dönemde sağlanan koşullar ve uygulamalar sahadaki performansı belirlemektedir. $\mathrm{Bu}$ süreçte meydana gelecek hatalar, telafisi mümkün olmayan performans kayıplarına sebep olmaktadır [5].

\section{Erken Dönemde Yumurta Sarısının Kullanımı}

Kuluçka aşamasında gelişen kanatlı embriyosunun tek enerji kaynağı yumurta sarısıdır. Trigliseridler (\%63) ve fosfolipidlerden (\%29) oluşan yumurta sarısı kuluçkadan çıkışta \%16-20 yă̆ ve \%20-25 protein içermektedir. İnkübasyonun 19. gününde kalan yumurta sarı kesesi abdominal boşluğa çekilmekte ve kuluçkadan çıkıştan yem yemeye başladıkları zamana kadar civcivlerin tek besin maddesi kaynağını oluşturmaktadır. Yumurta sarısı kuluçkadan çıkışta etlik civcivin canlı ağırlığının \%20-25'ini oluşturmaktadır [6]. 
Kuluçkadan çıkıştan sonra yumurta sarısı ya direkt kan dolaşımına ya da ince bağırsağa transfer olma yoluyla, kuluçkadan sonraki dönemde civcivlerin hem beslenmesi hem de ince bağırsağın gelişimi için kullanılmaktadır [7].

Yumurta, içerisinde protein, karbonhidrat, yağ, vitamin ve çeşitli iz elementleri bulunduran önemli bir besin kaynağıdır. Toplam yumurta ağırlığının yaklaşık \%11'ini yumurta kabuğu ve zarları, \%57'sini yumurta akı ve şalaz, \%32'sini ise yumurta sarıs1 meydana getirmektedir. Yumurtanın yapısı ve besin madde içerikleri sırasıyla Şekil 1 ve Tablo 1'de gösterilmiştir [8].

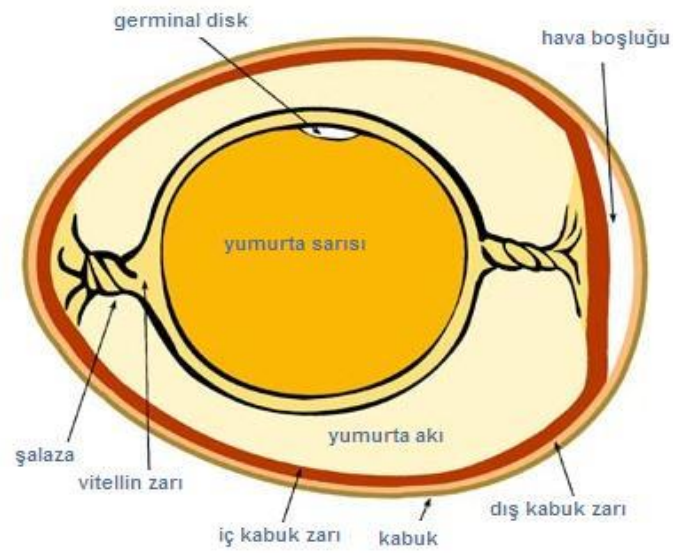

Şekil 1. Yumurtanın yapısı

Civcivin yaşama payı ve bağırsak gelişimi için kullanılan yumurta sarısinın besin madde içeriğinin büyük bir kısmı kuluçkadan çıkıştan sonraki 3 gün içerisinde tüketilmektedir. İnkübasyonun sonuna doğru civciv yüksek glukoz ihtiyacını karşılamak için kendi enerji rezervlerini kullanmaktadır [9].

Yumurta sarısının karbonhidrat içeriği düşük olduğu için glikoz, yağ ve proteinden sentezlenmektedir. Kuluçkadan sonraki dönemde civciv enerji kaynağı sentez metabolizması olarak glikolize ihtiyaç duymaktadır. Civcivlerde yumurta sarısı erken gelişim döneminde yeterli görünse de bu dönemde sarı içeriğinin besinsel olarak yetmemesi ve enerji için yağa gereksinim duyulması durumu sindirim sisteminin yeterli gelişememesi, bağışı sisteminin yeterli gelișememesi, ketosis ve vücutta kas protein rezervlerinin azalması gibi olumsuzluklara neden olabilmektedir [10].

\section{Erken Dönemde Kanatlıların Sindirim Sistemindeki Gelişmeler}

Kanatlılar tüm canlılarda olduğu gibi, hızlı morfolojik ve fizyolojik gelişim gösteren bir sindirim sistemi ile kuluçkadan çıkmaktadır. İnkübasyonun 19. gününde yumurta sarıs1 abdominal kesenin içerisine doğru çekilmekte, içerik ince bağırsağa nakledilmekte ve sindirilmektedir. Dolayısı ile canlı metabolizmasının başlangıcını sindirim sistemi oluşturmaktadır.

Kanatlılarda sindirim sistemini ağız, kursak, bezel mide, taşlık, ince bağırsak, kalınbağırsak ve körbağırsaklardan oluşturmaktadır. Karaciğer ve pankreas salgıladıkları sivilarla sindirime yardımc1 organlar olup sistem anatomik olarak ağızla başlayıp, ürogenital yolla birleşerek kloakla sona ermektedir. Kanatlliarda sindirim sisteminin anatomik yapısı Şekil 2' de gösterilmektedir.



Şekil 2. Kanatlı hayvanların sindirim sisteminin yapısı [11]

Kuluçkadan çıkıştan sonra civciv yaşamak ve vücut gelişimi sağlamak için sınırlı vücut rezervlerini kullanmakta ve bu rezerv vücudun diğer organlarına oranla daha çok mide-bağırsak sisteminin hızlı fiziksel ve fonksiyonel gelişimi için harcanmaktadır. Civcivin kuluçkadan çıkıștan ve yemlenmeye başlamasından sonraki tüm sindirim organlarının ağırlıkları yaklaşık olarak $\% 20$ düzeyinde artmaktadır [12].

Civcivler embriyonik gelișme esnasında pankreasta birikmiş olan tripsin, amilaz ve lipaz enzimi rezervleri ile kuluçkadan çıkmaktadır. Erken düzeyde bu enzimler sinırlıdır, fakat bu 
enzimlerin pankreas ve ince bağırsaktaki genel etkinlikleri kuluçkadan çıkışı takiben ilk günden itibaren artmaktadır. Erken dönem besleme uygulamalarının enzim etkinliğini arttırmada, mikrobiyal aktiviteyi iyileştirmede dolayısıyla sindirim sisteminin kilit bileşenleri üzerinde etkili olabileceği düşünülmektedir [13].

Tablo 1. Yaklaşık $60 \mathrm{~g}$ ağırlığında bir yumurtanın besin madde içeriği (\%)

\begin{tabular}{lllll}
\hline Besin Maddesi & Kabuklu Yumurta & Kabuksuz Yumurta & Yumurta Sarisi & Albumen \\
\hline Su & 65,6 & 73,6 & 48,7 & 87,8 \\
\hline Protein & 12,1 & 12,8 & 16,8 & 10,6 \\
\hline Yağ & 10,5 & 11,8 & 32,6 & - \\
\hline Karbonhidrat & 0,9 & 0,9 & 1,0 & 1,0 \\
\hline Kül & 0,9 & 0,8 & 1,0 & 0,6 \\
\hline
\end{tabular}

\section{Erken Dönemde Kanatlıların Bağışıklık Sistemindeki Gelişmeler}

Kanatlılarda bağışıklık sistemi, kendine özgü yapısal ve işlevsel özelliklere sahip olup, lenfoid sistemi vasıtasıyla gelişmektedir. Gelişmekte olan civciv embriyosuna ait ilk hücresel yap1; özel olmayan bağışıklık sistemine aittir ve fagositik hücreler tarafindan temsil edilmektedir. Bunlar kuluçkanın ilk günlerinde ortaya çıkar ve hemen çoğalırlar $[14,15]$.

Kuluçka sonrası civcivlerde de tüm canlılarda olduğu gibi genetik ve yapısal faktörlere ilave, bağ1şıklık sisteminin gelişmesi ve güçlenmesi canlının doğru zamanda, fonksiyonel yem tüketimiyle başlamaktadır. Kuluçka döneminde gelişmemiş olan lenf sisteminin iyi bir şekilde gelişmesi için yemlerin içerisindeki besin maddeleri önemlidir. Kuluçka dönemindeki stres, kortikosteroidlerin salgisını hizlandirmakta ve böylece bağışıklı hücrelerinin artışını önlemektedir. Kuluçkadan çıkışı takiben ilk 24 saat içerisinde kuluçka sonrası yem tüketen civcivlerde yem tüketmeyen kontrol grubundaki civcivlere nazaran ilk haftadaki ölüm oranları (\%5-8) ve enteritis vakalarının görülme düzeylerinin (\%34-49) daha düşük olduğu tespit edilmiştir. Civcivlerin erken dönemde beslenmemeleri, onların tüm yaşamları boyunca hastalıklara karşı dirençlerini etkilemekte ve bağışıklık sistemi üzerinde uzun süreli olumsuz etkiler yapmaktadır [16].

\section{Erken Dönem Besleme Uygulamaları}

Günümüzde olağan etlik piliç yetiştiriciliğinde hibritler daha kısa sürede (5-6 hafta) ve daha az yem tüketilerek $(3,3-4,7 \mathrm{~kg})$ daha yüksek canlı ağırlıklara (2,1- 2,8 kg) ulaşılabilmektedir [17]. Kesim yaşının giderek kısalması nedeniyle toplam ömrün yaklaşık \%45' ini oluşturan embriyonik dönem ve çıkış sonrası ilk hafta, performans ve sağlık açısından kritik periyotlar olarak kabul edilmektedir [18, 19].

Son y1llarda erken dönem beslemenin kuluçkadan çıkış öncesi dönemi (kuluçka dönemi) ve kuluçkadan çıkış sonrası dönemi olarak 2 farklı dönemde uygulanmasına yönelik araştırmalar yapılmaktadır. Erken dönem besleme çalışmalarının ilki inkübasyon süreci sonundaki (geç dönemdeki embriyonun amniyon sıvısına besin maddesi verilmesi) "in ovo" beslemeyken, ikincisi ise kuluçka çıkışı sonrası ilk 5 gün uygulanan "ön-başlatma" yemi uygulamasıdır. "In ovo besleme" olarak adlandırılan geç embriyonik dönemde amnion sivisina besin maddesi verilmesi veya civcivin kuluçkadan çıktıktan ilk beş gün süre ile özel bir yem ile beslenmesiyle civcivin sahip olduğu potansiyel genetik büyümeyi en yüksek düzeye çıkarmayı amaçlamaktadır [20].

Kuluçkadan çıkıştan birkaç gün önce embriyonun (geç dönem embriyo) amnion sıvısına sıvı besin maddesi (karbonhidratlar, amino asitler, proteinler, fonksiyonel yem bileşenleri) verilmesi, civcivin kuluçka çıkış ağırlığını artırmakta ve etkin etlik piliç üretimine olanak sağlamaktadır. Kritik gelişme aşamasında in ovo besleme tekniği ile daha kuluçka faaliyeti başlamadan civciv yem tüketmeye başlamakta, yemdeki besin maddelerinin daha etkin kullanımı sağlanmakta, kuluçka sonrası ölüm oranı azaltılmakta, bağırsak antijenlerine karşı bağışıklı sistemi güçlendirilmekte, bağırsak gelişimi artırılmakta, kas gelişimi ve göğüs eti randımanı yükseltilmeye çalışılmaktadır [19].

Kuluçkadan çıkışı takiben uygulanan ön-başlatma yemi ise 0-5. günler arasını kapsamaktadır. Civcivlerin kuluçkadan çıkıştan itibaren ilk birkaç gün süreyle nasıl beslendikleri onların tüm 
performanslarını önemli derecede etkilemektedir. Kuluçkadan çıkışı takiben civcivlerin yem ve su tüketimlerinde söz konusu olabilecek bir gecikme; canlı ağılık artışını azaltmakta, karkas randımanını ve diğer karkas bileşenlerini olumsuz yönde etkilemekte, sindirim ve bağışıklık sisteminin gelişimini yavaşlatmaktadır. Kuluçkadan çıkışı takiben ilk birkaç gün içerisindeki besleme, civcivlerin ince bağırsaklarında morfolojik ve fonksiyonel gelişmeyi hızlandırmaktadır. İnce bağırsak gelişiminde ve besin maddelerinin emilim yüzeyindeki artış, karkas randımanını artırmakta ve besi sonu canlı ağırlı̆̆ında dikkate değer bir artışa yol açmaktadır [21].

\section{6. İn Ovo Besleme}

Kuluçka döneminin son birkaç gününde embriyonun amniyon sivisina besin maddesi (karbonhidratlar, aminoasitler, proteinler, mineraller, vitaminler vb.) verilmesi olarak bilinen in ovo tekniği sayesinde civciv henüz yumurta içerisinde, inkübasyon sürecindeyken yem tüketmeye başlamaktadır.

İn ovo beslemenin yapılmasıyla, karın boşluğuna alınan yumurta sarı kesesi ağırlığ 1 arttırılarak kuluçka sonrası ölüm oranı azaltılmaya, enzim aktiviteleri (sükraz-izomaltaz ve amino-peptidaz) arttırılmaya, iştah arttırılarak kuluçka sonrası yem tüketimi uyarılmaya, bağırsak antijenlerine karşı bağ 1 şklık sistemi güçlendirilmeye, bağırsak gelişimi hızlandırılmaya, kas gelişimi ve göğüs eti randımanı yükseltilmeye çalışılmaktadır [19]. Ayrıca in ovo beslemede kuluçka gelişimi için mutlak gereksinim olan karbonhidratlar, glukoz için bir kaynak oluşturmakta, villus uzunluğu ve disakkaritlerin sindirimi için bağırsak kapasitesinin artırılmasıyla civcivler daha yüksek canlı ağırlığa ulaşabilmektedirler [22].

In ovo tekniği ilk olarak 1980'li yıllarının başında hastalıklarla mücadele yöntemiyle kullanılmıştır. Marek hastalığına karşı kuluçkanın 16-20. günleri arasında (18. günde) uygulanan in ovo aşılamanın çıkış gücünü etkilemeksizin hastalığa karşı büyük oranda koruma sağladığ gözlemlenmiştir [23]. Sonrasında bu yöntem ile kuluçkadaki civciv besleme ve performans güçlendirme teknikleri denenmiştir.

In ovo aşılamanın uygulanma zamanının belirlenmesinde embriyonik gelişim aşamalarının bilinmesi önemlidir. Yumurta içi enjeksiyonunda çeşitli inkübasyon süreleri denenmesine karşın optimum aralık kuluçkanın 17,5-19,5 günleri aralığında tutulmuştur [23, 24, 25, 26, 27].

Enjeksiyon uygulama zamanının yanı sıra diğer önemli süreç enjeksiyonun yeri ve enjeksiyonun derinliğidir. Wakenell ve ark. [28], en yüksek koruma derinliğinde enjeksiyonun, aşı hava hücresi ve allantoik sıvı geçilerek amniyotik sıv1 veya embriyo gövdesine uygulanmasının gerektiğini bildirmiş̧lerdir.

Embriyonun ağız yoluyla ilk öğünü prenatal dönemde amniyotik sıv1 vasitasıyla endojen besin maddelerinin alınması ile gerçekleşir [19]. Ekzojen besin maddelerinin tüketimi ise kuluçka çıkışı sonrası civcivlerin önüne koyulan yemin tüketilmesi ile gerçekleşir. In ovo tekniği ise ekzojen besin maddesi tüketiminin daha erken yaşta yani embriyonik dönemde başlamasına olanak sunmaktadır. Bu bağlamda, uygun besin madde solüsyonları amniyotik sıvıya enjekte edilerek embriyo tarafindan tüketilmesi, sindirilmesi ve emilmesi sağlanmaktadır [29]. In ovo besleme uygulaması ile prenatal dönemde özellikle yumurtadaki sınırlayıcı besin maddeleri destekleyerek kuluçka ve çıkış sonrası büyüme performanslarının iyileştirilmesi hedeflenmektedir [19]. Günümüze kadar konuyla ilgili birçok çalışma yapılmış ve farklı kanatlı türlerinde karbonhidrat [29], protein/amino asitler [30, 31, $32,33]$, vitaminler [34, 35, 36], mineraller [37], antikorlar [38], yem katk1 maddeleri (hormonlar/hormon benzeri maddeler, prebiyotik, simbiyotik ve organik asit vb.) $[39,40,41,42]$ ve arı ürünleri (polen, arı sütü, propolis, vb.) [43, 44, 45, 46] gibi çeşitli maddelerin etkileri incelenmiştir.

\section{7. Ön Başlatma Yemi Uygulamaları}

Noy ve Pinchasov [47], yumurtadan yeni çıkmış hindi civcivlerinin kursağına glukoz, nişaşta, yağ ve bunların karışımından oluşan solüsyonu tüp yoluyla verdiklerinde; kesim yaşı ağırlığına kadar canlı ağıllık kazancının arttı̆̆ını ve bu etkinin glukoz ve nişasta muamelelerinde daha belirgin olduğunu gözlemlemişlerdir.

Huff ve ark. [48], erken dönemde yeme propiyonik asit içerikli küf önleyici Mycocurb, Ca propiyonat, propiyonik asit katkısının etlik civcivlerde canlı ağırlık kazancı, bağırsak içeriğinin $\mathrm{pH}$ 's1 veya bağırsak direnci üzerine herhangi bir etki göstermediğini bildirmişlerdir.

Donaldson ve ark. [49], bir günlük yaştaki hindi civcivlerine $0,25 \mathrm{ml} \mathrm{Ca}$ propiyonat veya $\mathrm{Na}$ 
propiyonat solüsyonu enjekte (deri altı) etmişlerdir, 24 saat sonra kontrol grubuyla karşılaştırıldığında $\mathrm{Na}$ propiyonatın kan glukoz konsantrasyonunu arttırdığını, karaciğer ağırlığı ve karaciğer glukojenini üzerine ise kontrol grubu ile kıyaslandığında bir etkisinin olmadığını belirtmişlerdir. Ca propiyonatın ise kan glukoz seviyesi üzerine etkili olmadığ ağırlığında ve karaciğer glukojen konsantrasyonunu kontrol grubuna oranla arttırdığ 1 rapor edilmiştir. Yürüttükleri 2. denemede ise kontrol, suya Ca propiyonat, yeme $\% 4 \mathrm{Ca}$ propiyonat ve suya $\% 2 \mathrm{Ca}$ propiyonat + yeme $\% 4 \mathrm{Ca}$ propiyonat katmışlardır, yeme ve suya Ca propiyonat katkısının 48 saat sonra canlı ağırlığ 1 düşürdüğünü, yeme $\mathrm{Ca}$ propiyonat katkısının karaciğ er ağırlığını ve total karaciğer glukojenini düşürdüğünü belirtmişlerdir. Ortalama başlangıç ağırlığ 55 gr olan hindi civcivlerinin 48 saat sonra canlı ağırlıklarının kontrol grubu $72 \mathrm{~g}$, $\% 2$ suya Ca propiyonat ilave edilen grubun $64 \mathrm{~g}$, yeme $\% 2 \mathrm{Ca}$ propiyonat ilave edilen grubun $63 \mathrm{~g}$, suya $\% 2$ + yeme $\% 4 \mathrm{Ca}$ propiyonat ilave edilen grupta ise $60 \mathrm{~g}$ olduğu rapor edilmiştir.

Vieira ve Moran [50], broyler civcivlerin ilk bir haftalık büyütme döneminde $\% 3$ amonyum propiyonat katkılı yemle beslemişler, diğer 7 haftalık dönemde standart yemleme uygulamışlardır. Yeme propiyonat katkısının canlı ağırlık kazancını düşürdüğü buna karşılık yemden yararlanma oranını iyileștirdiğini, abdominal yağ oranının propiyonat katkısından etkilenmediğini bildirmişlerdir.

Dooren [51], yaptığı çalışmada kuluçkadan yeni çıkmış civcivlerin erken dönem beslemesinde süt ürünlerinin kullanım olanaklarını araştırmıştır. Kuluçkadan yeni çıkmış civcivlerin strese oldukça duyarlı olduğunu ve çeşitli nedenlerden dolayı yaşama güçlerinin azaldığını, süt ürünlerinin değerini belirlemek için laktoz, protein yağ gibi ayrı besin madde bileşenlerini rasyona ilave etmenin önemini belirterek; etlik civciv başlangıç yemine laktoz katkısının günlük su tüketimini arttırdığ1 ve performansı iyileştirdiğini, genel olarak süt proteininin diğer protein kaynaklarıyla karşılaştırıldığında yüksek bir sindirilebilirlik oranına (\%93-98) sahip olduğunu, ince partikül büyüklüğünde olan süt yağının yüksek oranda sindirildiğini ve genç civcivlerin hızlı gelişmelerine yardımcı olduğunu bildirmiştir.

Wojcik ve ark. [52], \%80 süt tozu, \%10 kırılmış keten tohumu küspesi, dikalsiyum fosfat, 2000.000 IU vit A, 180.000 IU vit D3, $3500 \mathrm{mg}$ vitamin $\mathrm{E} / \mathrm{kg}$ içeren $\mathrm{A}$ grubu yemi; \%80 glukoz,
$\% 8$ L-lisin, \%4 DL-metionin, dikalsiyum fosfat, $200 \mathrm{mg}$ vit B1, $600 \mathrm{mg}$ vitamin B2, $450 \mathrm{mg}$ vitamin $\mathrm{B} 6,300 \mathrm{mg}$ vitamin $\mathrm{C}^{\prime}$ den oluşan $\mathrm{B}$ grubu yemi olmak üzere iki ayrı grup yem hazırlamışlar ve kuluçkadan yeni çıkmış civcivleri 1.Kontrol 2.A grubu yem ile 5 gün 3. A grubu yem ile 10 gün 4 . B grubu yem ile 5 gün, 5. B grubu yem ile 10 gün, 6 . A ve B grubu yemler ile 10 gün besleme olmak üzere 6 gruba ayırmışlardır. 42. günde grupların sırasıyla canlı ağırlık kazançlarını 1903, 1968, 1941, 1901, 1912 ve 1866; yemden yararlanma oranlarını sirasiyla $1,76,1,75,1,80,1,74,1,74$ ve 1,74 ; karkas yağ yüzdesini ise $43,2,43,9,43,3,42,8,42,0$ ve 44,5 olarak bulmuşlardır.

Longo ve ark. [53], yapmış oldukları bir erken dönem besleme çalışmasında, kuluçkadan yeni çıkmış civcivlerde erken dönem beslemenin ileriki dönemdeki gelişmesini ve yağlanmasını etkilediği, civcivlerin yüksek sindirilebilirliğe sahip karbonhidrat kaynaklariyla beslenmesinin kan glukoz düzeyini artırmada olumlu etki yaptığını bildirmişlerdir. Bu sonuca ulaşmak için etlik civcivleri 4-7 günlük dönemde $\% 20$ oranında tapyoka nişastası, mısır nişastası, glukoz, laktoz (glukoz+galaktoz) ve sükroz (glukoz+früktoz) katkılı yemlerle beslemişlerdir. Sırasıyla tapyoka nişastası, mısır nişastası, glukoz, laktoz ve sükroz için gözlenebilir metabolize edilebilir enerjiyi (AMEn) içeriklerinin ilk bir haftalık dönemdeki civcivler için sırasıyla 3,$690 ; 3,269 ; 3,427 ; 3,225$ ve $3,524 \mathrm{kcal} / \mathrm{kg}$ olduğunu tespit etmişlerdir.

Ünsal [54], kuluçka sonrası ilk 10 günlük yaşta kullanılan pre-starter rasyonlara farklı karbonhidrat kaynakları ve yağların sindirimini kolaylaştırıcı emülsifiyer katkısının etlik civcivlerin canlı ağırlık kazancı, yem tüketimi, yemden yararlanma oranı, karkas özellikleri ve denemenin 10. ve 42. günlerinde sindirim sistemi gelişimine etkilerini incelemiştir. Erken dönemde yeme toz şeker, mısır nişastası, laktoz veya süt tozu katkısının denendiği birinci denemede, 7 . ve 14. günlerde $\% 4$ süt tozu katkıll etlik civciv başlangıç yemiyle beslenen grup diğer gruplarla karşılaştırıldığında yemden daha iyi yararlanma oranı göstermiştir $(\mathrm{P}<0.05)$, 42. gün itibariyle canlı ağırlık kazancı, yem tüketimi ve karkas özellikleri bakımından gruplar arasında herhangi bir istatistiki farkl111k gözlenmemiştir $(\mathrm{P}>0.05)$. Erken dönemde yeme propiyonik asit veya $\mathrm{Ca}$ propiyonat katkısının denendiği ikinci denemede, $\% 1$ veya $\% 2$ propiyonik asit katkılı etlik civciv başlangıç yemiyle beslenen gruplarda deneme sonu canlı ağırlık kazancı diğer gruplarla karşılaştırıldığında daha yüksek bulunmuştur 
$(\mathrm{P}<0.05)$. 0-21. günler arasinda yemden en iyi yararlanma ise $\% 2$ propiyonik asit katkıli yemle beslenen grupta bulunmuştur $(\mathrm{P}<0.05) . \% 3 \mathrm{Ca}$ propiyonat katkılı yemle beslenen grupta diğer gruplarla karşılaştırıldığında toplam sindirim sistemi ağırlığı düşmüştür $(\mathrm{P}<0.05)$. Erken dönemde yemde lesitin, süt tozu ve propiyonik asit kullanımlarının denendiği üçüncü denemede ise, 7. günde süt tozu+propiyonik asit katkılı yemle beslenen grubun canlı ağırlık kazancı diğer gruplarla karşılaştırıldığında daha yüksek bulunmuştur. Yemden yararlanma bakımından gruplar arasinda herhangi bir istatistiki farklılik bulunmamıştır. Denemenin 42. gününde en yüksek karaciğer ağırlığ1 \%4 süt tozu $+\% 2$ propiyonik asit katk1lı yemle beslenen grupta bulunmuştur $(\mathrm{P}<0.05)$. $\mathrm{Bu}$ bilgiler 1şığında kuluçka sonrası etlik civciv başlangıç yemine süt tozu, propiyonik asit veya lesitin katkısının performans üzerinde olumlu etkiye sahip olduğu ancak bu etkinin istatistiki olarak önemli olmadığ 1 belirtilmiştir.

Pinheiro ve ark. [55], etlik civcivlerde erken dönemde yem kisitlamasinın ve yeme enzim ilavesinin sindirim enzimleri aktivitesi üzerine etkisini araştırdıkları çalışmada kuluçkadan yeni çıkmış civcivler dört gruba ayrılmıştır. İki gruba 7. günden 14. güne kadar yem kısitlamas1 uygulanmış, diğer iki gruba yem ad libitum verilmiştir. Yem kısıtlaması yapılan ve enzim ilavesi uygulanan kanatlllarda maltaz aktivitesi yükselmiştir. Enzim ilavesi yapılarak beslenen ve erken dönemde yem kısıtlaması yapılan piliçlerin, 42 gündeki maltaz aktiviteleri daha yüksek çıkmıştır.

Tüzün [56], etlik civcivlerde yemlemeye geç başlamanın (48 saat) canlı ağırlık, canlı ağırlık artışı ve yem tüketimini önemli düzeyde düşürdüğünü, civcivlerde 48. saatte başlangıç ağırlığına göre \%8,98'lik bir azalma olduğunu, yem tüketiminde meydana gelen düşüklüğün, kesim yaşına kadar sürdüğünü bildirmiştir.

Ao ve ark. [57], etlik civcivlerde Clostridum perfringens enfeksiyonuna karşı yapmış oldukları çalışmada dört farklı rasyonun (4x2 faktöriyel) yanı sıra kuluçkadan hemen sonra yeme ve suya erişim (FED), 48 saat sonra yeme ve suya erişim (HELD) uygulaması yapmışlardır. Yapılan dört farklı rasyon uygulamasinda 1.grup negatif kontrol, 2.grup pozitif kontrol (Zn-basitrasin, antibiyotik), 3.grup yeme mannanoligosakkarit (MOS, \%0,02 kg), 4.grup yeme MOS+asitleştirici (Asid-Pak, \%0,03 kg) ilave etmişlerdir. Deneme sonucunda FED uygulaması yapilan civcivlerin 48 sa sonra yeme ulaşan civcivlerden daha fazla canlı ağırlık kazandığg ve daha az ölüm oranına sahip olduğu görülmüsştür. Bunun yanı sıra kuluçkadan çıkar çıkmaz 0.gün yeme ve suya ulaşımın sağlandığ 1 grupların diğer gruplara göre bağırsak lezyonları azalmış ve T-lenfositlerinde artış gözlenmiştir $(\mathrm{P}<0.05)$.

Pourreza ve ark. [58], broyler üzerinde yapmış oldukları erken dönem besleme çalışmasında denemede 300 etlik piliç kullanılmış performans sonuçlarını araştırmışlardır. 1.grup kontrol, 2.grup kuluçka sonrası ilk 48 saat süresince etlik piliç başlatma yemiyle beslenen, 3.grup kuluçka sonrası ilk 48 saat süresince rasyona ilave $\% 15$ yumurta tozuyla beslenen, 4.grup kuluçka sonrası ilk 48 saat süresince rasyona ilave $\% 15$ yumurta tozu ve $\% 20$ glikoz şurubu ile beslenen olmak üzere 5 farklı gruba ayırmıştır. Deneme sonuçlarına göre, deneme süresince $(1-42 \mathrm{~g})$ 5.grup 1.gruba göre daha fazla canlı ağırlık artışı göstermiştir $(\mathrm{P}<0.05) .1$ ile 7.günler aras1 2.grubun diğer gruplara göre yem tüketimi artmıștır $(\mathrm{P}<0.05)$. Ayrıca 7-21 g arası 2.grup diğer gruplara oranla daha yüksek yemden yararlanma oranına sahip olmuştur $(\mathrm{P}<0.05)$. Serum glikoz ve trigliserit oranı incelendiğinde en düşük oran 2.grupta gözlenirken LDL ve HDL kolesterol seviyeleri diğer gruplara göre artmıştır. Hematolojik parametreler ile ilgili gruplar arasında herhangi bir fark gözlemlenmemiştir.

\section{Sonuçar}

Kanatlı beslemede, besi başı ve besi sonu canlı ağırlığı arasında yüksek derecede bir ilişkinin bulunması, etlik piliç beslemede "erken dönem besleme" veya "ön-başlatma" yemi konusunun araştırılması ve uygulaması gerekliliğini ortaya koymuştur. Bu konuda günümüze kadar yapılan çalışmalarda bazı gelişmeler sağlanmış; ancak henüz yeterli ilerleme sağlanamamıştır. Kuluçka sürecinin sonunda embriyonun besin madde ihtiyacı ve dokuların gelişimi için gereksinme duyulan yumurta besin madde içeriği, midebağırsak sisteminin karbonhidrat ve proteince zengin yemden gelen besinleri sindirebilme kabiliyeti, kuluçkadan çıkışı takiben yumurta sarı kesesinde kalan besin madde içerikleri ve civcivin kuluçka sonrası ilk birkaç günlük dönemde yumurta sarısinda kalan besin maddelerine bağımlı olması geç dönem embriyonun yaşama gücünü, kuluçka çıkışını ve modern etlik piliç üretiminde potansiyel genetik büyümeyi sinırlayabilmektedir. $\mathrm{Bu}$ nedenle modern etlik civciv yetiştiriciliğinde erken dönem besleme büyük öneme sahiptir. 


\section{Çıkar Çatışması Beyanı}

Makale yazarları aralarında herhangi bir çıkar çatışması olmadığını beyan ederler.

\section{Araştırmacıların Katkı Oranı Beyan Özeti}

Yazarlar makaleye eşit oranda katkı sağlamış olduklarını beyan ederler.

\section{Kaynakça}

[1] Yang N., Jiang RS. Recent advances in breeding for quality chickens, World's Poultry Science Journal 2015; 61(3): 373381.

[2] Kutlu HR. Kümes Hayvanları Besleme Ders Notu 2015. Ç.Ü. Ziraat Fakültesi. Zootekni Bölümü, Adana.

[3] Kingston DJ. Some hatchery factors involved in early chick mortality, Australian Veterinary Journal 1979; 55: 418-421.

[4] Kop BC., Konan K., Ocak N., Öztürk E. Yumurta içi (in ovo) propolis enjeksiyonunun ve enjeksiyon yerinin kuluçka randımanı, civciv çıkış ağırlı̆̆ 1 ve yaşama gücüne etkileri, Türkiye Tarımsal Araştırmalar Dergisi 2016; 5(3): 48-54.

[5] Hill D. Chick length uniformity profiles as a field measurement of chick quality, Poultry Avian Biol Rev 2001; 12: 188 (Abstr).

[6] Noy Y., Sklan D. Yolk and exogenous feed utilization in the post-hatch chick, Poultry Science 2001; 80(10): 1490-1495.

[7] Noy Y., Sklan D. Energy utilization in newly hatched chicks. Poultry Science 1999; 78(12): 1750-1756.

[8] Aksoy T. Tavuk yetiştiriciliği. Ankara Üniversitesi Veteriner Fakültesi Zootekni A.B.D. Ankara; 1999.

[9] Christensen VL., Wireland MJ., Farenko GM., Donaldson WE. Egg storage effects plasma glucose and supply and demand tissue glycogen concentrations of broiler embryos, Poultry Science 2001; 80(12): 1729-1735.

[10] Vieira SL., Moran ET. Effects of egg origin and chick posthatch nutrition on broiler live performance and meat yields, Word's Poultry Science Journal 1999; 56(4): 125-142.
[11] LarbIer M., Leclercq B. Nutrition and feeding of poultry. Nottingham (UK). Nottingham University Press, 1994.

[12] Sklan D. Development of the digestive tract of poultry, World's Poultry Science Journal 2001; 57(4): 415-428.

[13] Nitsan Z. The development of digestive tract in posthatched chicks. 10th European Symposium on Poultry Nutrition, October 15-19th, 1995, 21-28p.

[14] Cooper MD., Peterson RD., South MA., Good RA. The functions of the thymus system and the bursa system in the chicken, The Journal of Experimental Medicine 1966; 123(1): 75-102.

[15] Panda AK., Reddy MR. Setting chicks off to a good start-Boosting the chick's immune system through early nutritionResearch shows that chicks that feed soon after hatching are healthier and get off to a better start, Poultry International 2007; 46(7): 22-27.

[16] Dibner J. Feeding hatchling poultry, Feed Int 1999; 12: 30-34.

[17] Aviagen. Broiler Management Handbook 2018; 1118-AVNR-032.

[18] Bigot K., Mignon-Grasteau S., Picard M., Tesseraud S. Effect of delayed feed intake on body, intestive and muscle development in neonate broilers, Poultry Science 2003; 82(5): 781-788.

[19] Uni Z., Ferket RP. Methods for early nutrition and their potential, World's Poultry Science Journal 2004; 60(1):101111.

[20] Beiglou RE. The effect of in-ovo feeding on intestinal development and performance of avian species, Tavukçuluk Araştırma Dergisi 2004; 9(1): 34-41.

[21] Geyra A., Uni Z., Sklan D. Enterocyte dynamics and mucosal development in the posthatch chick, Poultry Science 2001; 80(6): 776-782.

[22] Tako E., Ferket PR., Uni Z. Effects of in ovo feeding of carbonhydrates and $\beta$ hydroxy- $\beta$ methylbutyrate on the development of chicken intestine, Poultry Science 2004; 83(12): 2023-2028.

[23] Sharma JM., Burmester BR. Resistance of Marek's disease at hatching in chickens vaccinated as embryos with the turkey 
herpesvirus, Avian Diseases 1982; 134149.

[24] De Souza FM. Basic aspects of in ovo injection in commercial hatcheries, CEVA Sante Anim 2008; 3-6.

[25] Williams CJ. U.S. Patent No. 6,032,612. Washington, DC: U.S. Patent and Trademark Office 2000.

[26] Moosanezhad M., Salahi A., Mashayekhi $\mathrm{S}$. The best time for in ovo solution injection in old broiler breeder flock eggs. In XIV European Symposium on the Quality of Eggs and Products. XX European Symposium on the Quality of Poultry Meat 2011; 4-8.

[27] Salahi A., Mozhdeh MK., Seyed NM. Optimum time of in ovo injection in eggs of young broiler breeder flock, 18th Eur. Symp. on Poultry Nutrition 2011; 557559 p.

[28] Wakenell PS., Bryan T., Schaeffer J., Avakian A., Williams C., Whitfill C. Effect of in ovo vaccine delivery route on HVT/SB-1 efficacy and viremia, Avian Disease 2002; 46(2): 274-280.

[29] Uni Z., Tako E., Gal-Garber O., Sklan D. Morphological, molecular and functional changes in the chicken small intestine in the late term embriyo, Poultry Science 2003; 82(11): 1747-1754.

[30] Awachat VB., Elangovan AV., David CG., Ghosh J., Bhanja SK., Majumdar S. Influence of in ovo and pre-starter amino acid supplementation on growth performance and immune response in broiler chicken, Animal Nutrition and Feed Technology 2018; 18(1): 55-66.

[31] Bhanja S., Mandal A. Effect of in ovo injection of critical amino acids on preand post-hatch growth, immunocompetence and development of digestive organs in broiler chickens, Asian-Australasian Journal of Animal Sciences 2005; 18(4): 524-531.

[32] Kadam MM., Bhanja SK., Mandal AB., Thakur R., Vasan P., Bhattacharyya A., Tyagi JS. Effect of in-ovo threonine suplementation on early growth, immunological responses and digestive enzyme activities in broiler chickens, British Poultry Science 2008; 49(6): 736741.
[33] Salmanzadeh M., Ebrahimnezhad Y., Shahryar HA., Lotfi A. The effects of in ovo injection of L-threonine in broiler breeder eggs on characters of hatching and growth performance broiler chickens, European Journal of Experimental Biology 2011; 1(4): 164-168.

[34] Bhanja SK., Mandal A., Agarwal SK., Majumdar S., Bhattacharyya A. Effect of in ovo injection of vitamins on the chick weight and post-hatch growth performance in broiler chickens, World Poultry Science Association, Proceedings of the 16th European Symposium on Poultry Nutrition 2007; 143-146p.

[35] İpek A., Şahan Ü., Yılmaz, B. Effect of in ovo ascorbic acid and glucose injection in broiler breeder eggs on hatchability and chick weight, Archiv Für Geflügelkunde 2004; 68(3): 132-135.

[36] Yılmaz Ç. Yumurta içi (in ovo) Vitamin C ve Vitamin $\mathrm{E}$ uygulamasının kuluçka parametreleri ile civcivlerin performansına etkileri, Yüksek Lisans Tezi. Çukurova Üniversitesi Fen Bilimleri Enstitüsü, Adana, 2017.

[37] Yair R., Shahar R., Uni Z. Prenatal nutritional manipulation by in ovo enrichment influences bone structure, composition, and mechanical properties, Journal of Animal Science 2013; 91(6): 2784-2793.

[38] Wu YJ., Valdez-Corcoran M., Wright J T., Cartwright AL. Abdominal fat pad mass reduction by in ovo administration of anti-adipocyte monoclonal antibodies in chickens, Poultry Science 2000; 79(11): 1640-1644.

[39] Hargis P., Pardue S., Lee A., Sandel G. In ovo growth hormone alters growth and adipose tissue development of chickens, Growth Development and Aging 1989; 53(3): 93-99.

[40] Lamosova D., Macajova M., Zeman M., Mozes S., Jezova D. Effect of in ovo leptin administration on the development of Japanese quail, Physiological Research 2003; 52(2): 201-209.

[41] Pruszynska-Oszmalek E., Kolodziejski PA., Stadnicka K., Sassek M., Chalupka D., Kuston B., Nogowski L., Mackowiak P., Maiorano G., Jankowski J., Bednarczyk M. In ovo injection of 
prebiotics and synbiotics affects the digestive potency of the pancreas in growing chickens, Poultry Science 2015; 94(8): 1909-1916.

[42] Salahi A., Adabi SG., Khabisip MM., Anissian A., Cooper RG. Effect of In ovo administration of butyric acid into broiler breeder eggs on chicken small intestine $\mathrm{pH}$ and morphology, Slovak Journal of Animal Science 2015; 48(1): 8-15.

[43] Jafari AY., Hashemi SR., Akhlaghi A., Atashi H., Esmaili Z., Ghorbani M., Davoodi H. Effect of in ovo injection of royal jelly on post-hatch growth performance and immune response in broiler chickens challenged with newcastle disease virüs, Iranian Journal of Applied Animal Science 2013; 3(1): 201-206.

[44] Coşkun İ., Çayan H., Yılmaz Ö., Taşkın A., Tahtabiçen E., Şamlı HE. Effects of in ovo pollen extract injection to fertile broiler eggs on hatchability and subsequent chick weight, Turkish Journal of Agricultural and Naturel Sciences 2014; 1(4): 485-489.

[45] Aygun A. The effects of in-ovo injection of propolis on egg hatchability and starter live performance of Japanese Quails, Brazilian Journal of Poultry Science 2016; 18(2): 83-89.

[46] Kop BC., Konan K., Ocak N., Öztürk E.. Yumurta içi (İn Ovo) propolis enjeksiyonunun ve enjeksiyon yerinin kuluçka randımanı, civciv çıkış ağırlığı ve yaşama gücüne etkileri, Türkiye Tarımsal Araştırmalar Dergisi 2016; 3(1): 48-54.

[47] Noy Y., Pinchasov Y. Effect of a single posthatch intubation of nutrients on subsequent early performance of broiler chicks and turkey poults, Poultry Science 1993; 72(10): 1861-1866.

[48] Huff WE., Balog CM., Bayarı GR., Rath, NC. The effect of mycocurb, propionic acid, and calcium propionate on the intestinal strength of broiler chickens, Poultry Science 1994; 73(8): 1352-1356.

[49] Donaldson WE., Christensen VL., Ferket PR. Administration of propionate to day old turkeys, Poultry Science 1994; 73(8): 1249-1253.
[50] Vieira SL., Moran ET. Effects of egg origin and chick posthatch nutrition on broiler live performance and meat yields, Word's Poultry Science Journal 1999; 55(2): 125-142.

[51] Dooren IP. The use of milk products in young poultry nutrition, International Poultry Production 2001; 9(5): 24-25.

[52] Wojcik S., Adamczyk M., Niedwiadek T. The effect of some nutrients on growth of chikcs after hatching, Buletyn Nkowy Przemys Pszoweg 2001; 20(1): 5-15.

[53] Longo FA., Menten JFM., Sorbara JOB., Pedroso AA., Figueiredo AN. Metabolizable energy of carbohydrates for newly hatched broiler chicks, Poultry Science Association 92nd Annual Meeting Abstracts. July 6-9, 2003. Monona Terrace, Madison, WI.

[54] Ünsal İ. Erken dönem besleme uygulamalarının etlik civcivlerin gelişimine etkileri, Doktora Tezi, Ç.Ü. Fen Bilimleri Enstitüsü, Adana, 2004.

[55] Pinheiro SRF., Barreto SLDT., Albino L FT., Rostagno HS., Umigi RT., Brito CO. Efeito dos níveis de triptofano digestível em dietas para codornas japonesas em postura, Revista Brasileira de Zootecnia 2008; 37(6): 1012-1016.

[56] Tüzün CG. Effects of feed accessing time after hatching on the methionine requirements, performances and digestive system development of broiler chicks. 2009.

[57] Ao Z., Kocher A., Choct M. Effects of dietary additives and early feeding on performance, gut development and immune status of broiler chickens challenged with Clostridium perfringens, Asian-Australasian Journal of Animal Sciences 2012; 25(4): 541.

[58] Pourrez J., Zamani F., Tabeidian A., Toghyani M. Effect of early feeding or feed deprivation on growth performance of broiler chicks, Research Opinions in Animal and Veterinary Sciences 2012; 2(2): 136-140. 